\title{
KONCEPCJA URBAN RESILIENCE: NARZĘDZIE STRATEGICZNEJ DIAGNOZY I MONITORINGU MIAST
}

\section{WPROWADZENIE}

Problematyka opracowania nawiązuje do nowej koncepcji badawczej miast związanej z prężnością miejską (urban resilience). Wnioski przedstawione w artykule stanowią rezultat projektu badawczego finansowanego ze środków Narodowego Centrum Nauki (nr 2011/01/B/HS5/03257): Koncepcja „urban resilience" a miasta poprzemystowe $w$ Europie, realizowanego w latach 20112014, także przy wsparciu międzynarodowej sieci badawczej Regional Studies Association: Transition and Resilience for Post-Industrial Agglomerations in Central Europe (2011-2013). Badania powyższe były realizowane przez zespół składający się z przedstawicieli: Uniwersytetu Ekonomicznego w Katowicach, Uniwersytetu Technicznego w Ostrawie, Uniwersytetu Strathclyde w Glasgow oraz Wyższej Szkoły Zawodowej w Lipsku (Hochschule für Technik, Wirtschaft und Kultur). W wymiarze praktyki gospodarczej zespół badawczy został uzupełniony o przedstawicieli urzędów Miasta Katowice oraz Miasta Bytomia.

Celem artykułu jest prezentacja propozycji metodyki badawczej dotyczacej oceny prężności miejskiej wraz z jej wstępną weryfikacją dla wybranych miast $\mathrm{w}$ Polsce, w tym tych o rodowodzie poprzemysłowym. Uzupełnienie stanowi krótki przegląd założeń teoretycznych odnoszących się do koncepcji prężności miejskiej, w tym w kategoriach ekonomicznych. Istotną częścią artykułu są wnioski odnoszące się do wykorzystania koncepcji prężności miejskiej w procesie strategicznej diagnozy i monitoringu miast.

\section{ZAŁOŻENIA KONCEPCJI URBAN RESILIENCE}

Wykorzystanie koncepcji prężności oraz prężności miejskiej w problematyce transformacji miast stanowi relatywnie nowa ideę $\mathrm{w}$ diagnozowaniu oraz planowaniu rozwoju lokalnego. Ośrodki miejskie coraz częściej podlegają silnej presji ze strony otoczenia wymuszającej ich transformację. Miasta stoją w obliczu wielu problemów wewnętrznych oraz wyzwań o charakterze 
zewnętrznym, np. starzenie się społeczeństwa, wykluczenie społeczne, preferencje mieszkaniowe, degradacja środowiska i krajobrazu miejskiego, kryzysy globalne i branżowe, katastrofy naturalne. Pewna grupa miast skutecznie adaptuje się do tego rodzaju zmian, podczas gdy w innych zmiany strukturalne prowadzą do stagnacji i regresu. W tym kontekście koncepcja prężności miejskiej jest podejściem użytecznym z punktu widzenia analizy i monitoringu zachodzących przemian, a także podejmowania działań przygotowawczych do wyzwań otoczenia.

W literaturze można spotkać znaczącą liczbę publikacji traktujących o miastach zrównoważonych (sustainable city), miastach inteligentnych (smart city), miastach zielonych (green city), miastach konkurencyjnych (competetive city), miastach kreatywnych oraz atrakcyjnych (creative and attractive city),

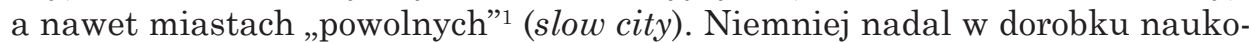
wym występuje relatywnie nieduża liczba pozycji poświęconych czynnikom determinującym prężność i wrażliwość miast, a także odnoszących się do oceny prężności miejskiej w kategoriach diagnozy strategicznej.

Właczenie do debaty na temat rozwoju miejskiego kategorii prężności miejskiej (urban resilience) ${ }^{2}$, prężnego miasta (resilient city) oraz miasta wrażliwego (vulnerable city) miało miejsce podczas debat poświęconych zagadnieniom zrównoważonego rozwoju, w tym adaptacyjności do zmian klimatycznych ${ }^{3}$. Początkowo pojęcia te rozważane były głównie w kontekście największych miejskich zagrożeń i katastrof, jak przykładowo: ataki terrorystyczne w Nowym Jorku, katastrofy naturalne w Azji związane z tsunami, czy też szkody wyrządzone przez huragan Katrina w Nowym Orleanie.

W ujęciu ogólnym pojęcie prężności definiowane jest jako: zdolność systemu do odzyskania swoich własności po doświadczeniu zakłóceń, szoków ${ }^{4}$. Wśród opracowań poświęconych tematyce prężności spotkać można wiele nieścisłości wokół tego terminu i prawdopodobnie trudno jest doszukać się jednoznacznej definicji analizowanego pojęcia zarówno w ekonomice miejskiej i regionalnej, jak i innych naukach społecznych, technicznych czy środowiskowych. W konsekwencji sprzyja to wieloznacznym ujęciom kategorii prężności, która może być postrzegana jako:

- reakcja systemu na specyficzne, niezwykłe wydarzenia i szoki ${ }^{5}$,

- zdolność unikania i zarządzania zagrożeniami naturalnymi oraz tymi, które zostały wywołane przez człowieka ${ }^{6}$,

1 Zastosowano tłumaczenie dosłowne, popularne w tym zakresie jest używanie kategorii „cittaslow" m.in. przez Międzynarodową Sieć Miast Cittaslow.

${ }^{2} \mathrm{~W}$ tłumaczeniach w literaturze polskojęzycznej można również spotkać pojęcie „miasta odpornego”, niemniej w tym ujęciu kategoria „resilience” odnosi się raczej do systemów środowiskowo-infrastrukturalnych, w tym związanych z bezpieczeństwem, por. A. Jasiński, Architektura $w$ czasach terroryzmu. Miasto-przestrzeń publiczna-budynek, Lex a Wolters Kluwer Business, Warszawa 2013, s. 242.

${ }^{3}$ J. Simme, R. Martin, The Economic Resilience of Regions: Towards an Evolutionary Approach, „Cambridge Journal of Regions, Economy and Society” 2009, s. 1-17.

${ }^{4}$ Ibidem.

5 Ibidem.

${ }^{6}$ L. Bosher, N. Coaffee, Editorial: International Perspective on Urban Resilience, „Urban Design and Planning” 161, 2008, nr DP4, s. 145-146. 
- stabilność systemu względem zakłóceń, jednak nieograniczająca się wyłącznie do odpowiedzi lub zmagania się z wyzwaniami, ale swego rodzaju własność, którą dany system posiada ${ }^{7}$,

- koncept umożliwiający zrozumienie, zarządzanie, kierowanie kompleksowymi społeczno-ekologicznymi systemami ${ }^{8}$.

Samo pojęcie prężności miejskiej jest natomiast rozumiane jako stopień, do którego miasta są zdolne tolerować zmienność otoczenia, zanim zreorganizują nowy zestaw struktur i procesów. Stąd prężność miejska może być także postrzegana w kontekście stopnia, w jakim miasto jest zdolne równocześnie równoważyć ekosystem (środowisko naturalne) z funkcjami antropogenicznymi (system społeczno-ekonomiczny). Zatem prężność miejska nie ogranicza się wyłącznie do „odpowiedzi na zewnętrzny wpływ otoczenia”, jak przykładowo katastrofa czy kryzys ekonomiczny, ale oznacza także społeczność i gospodarkę lokalną, które są elastyczne, tj. zdolne do dostosowania się do zmiennych warunków ${ }^{9}$.

W powyższym rozumieniu ekonomiczna prężność miejska może być utożsamiana ze zdolnością miasta do rozwiązywania problemów społeczno-ekonomicznych w sposób umożliwiajacy osiagnięcie długookresowego sukcesu. Jak zauważają Simme i Martin, ekonomiczna prężność miejska to zdolność do kapitalizowania szans, które mogą pojawić się w przyszłości ${ }^{10}$, oraz minimalizowania zagrożeń. Wśród charakterystyk, które pozwalają opisywać kategorię ekonomicznej prężności miejskiej, wymienia się następujące:

- zdolność miasta do skutecznej regeneracji własnej gospodarki po doświadczonym zakłóceniu, tj. zakłóceniu, które zmieniło dotychczasową ścieżkę rozwoju gospodarczego lub posiada potencjał do takiej zmiany,

- zdolność miasta do antycypowania, przygotowania się, odpowiedzi i regeneracji po doświadczeniu zakłóceń,

- zdolność gospodarki miasta do utrzymania lub powrotu do stanu sprzed egzogenicznego szoku, tj. powrót do poprzedniego poziomu wzrostu, poprzedniej wielkości produkcji, poprzedniej stopy zatrudnienia oraz poziomu populacji ${ }^{11}$.

Kilka następujących aspektów związanych z koncepcją prężności miejskiej, z punktu widzenia jej zastosowania w monitorowaniu i planowania rozwoju miejskiego, wymaga dodatkowego wyjaśnienia. W ramach prężności miejskiej

\footnotetext{
${ }^{7}$ R. Welter-Enderlin, Resilienz - Gedeihen trotz widriger Umstände, Carl-Auer-Systeme, Heidelberg 2006.

${ }^{8}$ B. Walker, D. Salt, Resilience Thinking: Sustaining Ecosystems and People Changing World, Island Press, Washington 2006.

9 J. Barnett, Adapting to Climate Change in Pacific Island Communities, „World Development” 29, 2001, s. 977-993; K. A. Foster, A Case Study Approach to Understanding Regional Resilience. Working Paper 2007-08. Institute of Urban and Regional Development, University of California, Berkeley 2007.

${ }^{10}$ J. Simme, R. Martin, op. cit.

${ }^{11}$ M. Alberti, Integrating Humans into Ecology: Opportunities and Challenges for Studying Urban Ecosystems, „BioScience” 53, 2003, s. 1169-1179; J. Barnett, op. cit.; K. A. Foster, op. cit.; J. Simme, R. Martin, op. cit.; E. Hill, T. Clair, H. Wial et al., Economic Shocks and Regional Economic Resilience, George Washington, Urban Institute, Building Resilience Region Project, Conference on Urban and Regional Policy and Its Effects: Building Resilience Regions, Washington DC, May 20-21, 2010.
} 
twierdzi się, że gospodarka miasta, która jest nieznacznie dotknięta skutkami szoku zewnętrznego, o wiele szybciej powraca do stanu pierwotnego niż gospodarka, która została znacząco osłabiona. W ramch koncepcji prężności miejskiej bada się nie tylko problem stabilności lokalnej gospodarki, lecz także zagadnienia wrażliwości ekonomiki miejskiej na zewnętrzne zakłócenia. Szczególnie interesującym zagadnieniem jest rozróżnienie zdolności lokalnej gospodarki do utrzymania swoich struktur oraz jej zdolności do szybkiej zmiany struktur jako odpowiedzi na zewnętrzne zakłócenia. Koncepcja prężności miejskiej pozwala także na poszukiwanie odpowiedzi na pytanie związane z jednym z wymiarów diagnozy strategicznej miasta, tj. jak ocenić stopień ekonomicznej prężności miasta lub też stopień jego wrażliwości na zakłócenia. W tym ujęciu może być postrzegana jako narzędzie strategicznej diagnozy i monitoringu miast.

Reasumując powyższe rozważania, można stwierdzić, iż z jednej strony ekonomiczna prężność miejska odnosi się do stopnia, w jakim miasto jest zdolne utrzymać istniejące struktury społeczno-gospodarcze poprzez akumulowanie wpływu otoczenia. Z drugiej zaś ekonomiczna prężność miejska wiąże się z oceną możliwości, czy i jak miasto jest zdolne przeprowadzić szybka transformację struktur społeczno-ekonomicznych. Kategorię ekonomicznej prężności miejskiej można postrzegać jako zmienną w czasie. Prężność może zależeć od charakteru i stopnia zakłóceń generowanych przez otoczenie miasta, a także od zdolności miasta do ewolucji własnych struktur. Zatem w ramach koncepcji prężności miejskiej wyróżnia się dwa podstawowe podejścia badawcze ${ }^{12}$, odnoszące się do:

- równowagi ekonomicznej,

- ewolucji.

Podejście związane z równowaga ekonomiczną podkreśla zdolności systemu miejskiego do powrotu do poprzedniego punktu równowagi ${ }^{13}$ lub też przejście do nowego punktu równowagi po ustaniu zakłóceń; jest ono uznawane za tradycyjne. Czasami bywa określane mianem „prężności inżynieryjnej” (engineering resilience). Akcent wnioskowania skupia się w nim głównie na stabilności systemu miejskiego wokół punktu równowagi lub też powrotu do punktu równowagi ekonomicznej po zakłóceniach generowanych przez otoczenie. Prężność w tym ujęciu jest rozumiana także jako zdolność systemu miejskiego do absorpcji i akumulacji zakłóceń bez transformacji struktur miejskich. Oznacza to, że zakłócenia wytrącaja gospodarkę miasta z punktu równowagi i dotychczasowej ścieżki wzrostu, natomiast przy założeniu występowania sił samokorygujących, następuje powrót miasta do punktu równowagi i poprzedniej ścieżki wzrostu. Kontrowersje wokół podejścia równowagi ekonomicznej wiążą się z następującym problemem: jeśli za prężna gospodarkę miejską uważa się taka, która posiada zdolność powrotu do punktu równowagi po doznanych turbulencjach, to pojawia się trudność pogodzenia tego twierdzenia z idea rozwoju miejskiego w ujęciu jakościowym, ponieważ im bardziej prężne jest miasto, tym w mniejszym stopniu zmienia się w czasie.

12 E. Hill, T. Clair, H. Wial et al., op. cit.; J. Simme, R. Martin, op. cit.

13 S. L. Pimm, The Complexity and Stability of Eco-systems, „Nature” 1984, nr 307, s. 321-326. 
Podejść ewolucyjne zakłada z kolei, że miasta stanowią kompleksowe systemy adaptacyjne, które charakteryzuje żywotność, dynamika, połączalność i otwartość. Systemy miejskie nieustannie ewoluują na wiele różnorodnych sposobów w odpowiedzi zarówno na wewnętrzne interakcje, jak i ze względu na wpływ czynników otoczenia ${ }^{14}$. Podejście ewolucyjne, w przeciwieństwie do podejścia równowagi ekonomicznej, bazuje na „prężności ekologicznej” (ecological resilience). Tak postrzegana prężność ukierunkowana jest na rozwiązanie następującego problemu: Czy i w jakim stopniu turbulencje doprowadzą miasto do zmiany dotychczasowej ścieżki rozwoju? Za prężna gospodarkę miasta uznaje się taka, która jest zdolna do absorbowania i akumulowania zakłóceń otoczenia bez znaczącej zmiany struktur, lub też taka, która jest zdolna do skutecznego wykreowania nowych struktur społeczno-gospodarczych w krótkim czasie po doświadczeniu zewnętrznych zakłóceń. W podejściu ewolucyjnym nie istnieje pojedynczy punkt równowagi, pojedyncza ścieżka rozwoju, ale kilka możliwych stanów równowagi i ścieżek rozwoju. Gospodarka miasta może być przesunięta z jednego punktu równowagi do następnego, z jednej ścieżki rozwoju na inną w wyniku doznanego zakłócenia. Prężna gospodarka miejska to taka, która $\mathrm{z}$ sukcesem adaptuje się, powraca lub ciagle poprawia swoje długookresowe ścieżki rozwoju. Analogicznie miejską gospodarkę uważa się za wrażliwa, jeśli zawodzi w transformacji i pozostaje „zamknięta” w starych strukturach obniżających poziom jej ścieżki wzrostu.

\section{PRĘŻNOŚĆ W BADANIACH MIEJSKICH I REGIONALNYCH}

Rosnąca popularność problematyki prężności w naukach społecznych spowodowała wzrost dorobku naukowego, także w kierunkach związanych z ekonomiką miejską i regionalną. Głównymi przedstawicielami miejskiego i regionalnego ujęcia prężności są: Wial, Wolman ${ }^{15}$, Gerst, Doms, Daly ${ }^{16}$, Hill ${ }^{17}$, Hassink $^{18}$, Cumming ${ }^{19}$, Cooke ${ }^{20}$, Eraydin, Taşan-Kok ${ }^{21}$. Ponadto zalicza się do nich:

${ }^{14}$ M. Batty, J. Barros, S. Alves, Cities: Continuity, Transformation, and Emergence, CASA Working Paper Series, Number 72, Centre for Advanced Spatial Analysis, University Colleague, London 2004.

${ }^{15}$ E. Hill, H. Wial, H. Wolman, Exploring Regional Economic Resilience, Working Paper, Institute of Urban and Regional Development, University of California, 2008, No. 04.

${ }^{16}$ J. Gerst, M. Doms, M. C. Daly, Regional Growth and Resilience: Evidence from Urban IT Centers, „FRBSF Economic Review” 2009, s. 1-11.

17 E. Hill, T. Clair, H. Wial et al., op. cit.

${ }_{18}$ R. Hassink, Regional Resilience: A Promising Concept to Explain Differences in Regional Economic Adaptability?, „Cambridge Journal of Regions, Economy and Society” 3, 2010, nr 1, s. $45-58$.

19 G. S. Cumming, Spatial Resilience in Social-Ecological Systems, Springer, Dordrecht 2011.

${ }^{20}$ Ph. Cooke, M. D. Parrilli, J. L. Curbelo (red.), Innovation, Global Change and Territorial Resilience, Edward Elgar, Cheltenham 2012.

21 A. Eraydin, T. Taşan-Kok, Introduction: Resilience Thinking in Urban Planning, w: iidem (red.), Resilience Thinking in Urban Planning, Springer, Dordrecht 2013. 
- Gleasera i Saiza ${ }^{22}$, którzy prowadzili badania związane ze znaczeniem kapitału ludzkiego w kontekście prężności regionalnej. Zgodnie z ich wynikami kapitał ludzki wraz z poziomem wykształcenia oraz umiejętnościami regionalnej siły roboczej sa głównymi czynnikami wzrostu i prężności;

- Briguglia ${ }^{23}$, który badał koncentrację krajowych eksporterów zgromadzonych w kilku branżach przemysłu. Wyniki jego studiów wskazuja, że tego rodzaju koncentracja osłabia prężność, co sugeruje, że podobna sytuacja może mieć miejsce w przypadku regionalnie i lokalnie nadmiernej koncentracji przemysłów tego rodzaju;

- Duvala ${ }^{24}$, który prowadził studia odnoszące się do polityki ograniczającej możliwości zwalniania pracowników przez firmy i przenoszenia ich do innych prac. Tego rodzaju ograniczenia prawne powoduja, że ewentualne szoki ekonomiczne przebiegaja w mniej ostry sposób (np. mniejsza dynamika spadku zatrudnienia), jednak ich skutki odczuwane są w dłuższym czasie. Podobne efekty względem prężności odnoszone są do polityki ograniczającej grupowe zwolnienia i promującej aktywność związków zawodowych;

- Feyrera ${ }^{25}$, prowadzacego badania nad regionami, w których likwidowano miejsca pracy w sektorze motoryzacyjnym oraz w hutnictwie w późnych latach siedemdziesiątych i na początku lat dziewięćdziesiątych w Stanach Zjednoczonych. Zgodnie z ich wynikami zatrudnienie i populacja w tych regionach wzrastały nieznacznie nawet kilka lat po doświadczeniach szoku ekonomicznego, po czym znacząco obniżyły się, by wzrosnąc dopiero po dwóch dekadach. Regiony $\mathrm{z}$ dominacją przemysłu motoryzacyjnego lub hutnictwa były bardziej odporne na szok, jeśli w ich pobliżu znajdowały się duże obszary metropolitalne;

- Christophersona i Clarka ${ }^{26}$, wyniki ich badań wskazują na zależność pomiędzy wzrostem gospodarczym oraz prężnością regionalną a dominacją kilku pionowo zintegrowanych dużych przedsiębiorstw, które dominują regionalny rynek pracy, dostawców, działalności B+R, kanały informacji oraz stowarzyszenia biznesowe. Tego rodzaju dominacja hamuje wzrost oraz ogranicza prężność;

- Nunna ${ }^{27}$, który twierdzi z kolei, że specyficzne instytucje regionalne, normy zachowań, wiedza oraz technologia wywieraja długookresowy wpływ na rozwój regionów i w ten sposób istotnie determinują poziom ich prężności;

- Desmeta i Rossi-Hansberg28, którzy zauważaja, że prężność miejska może ulec wzmocnieniu, jeśli firmy zlokalizowane w danym mieście potrafia

${ }^{22}$ E. L. Gleaser, A. Saiz, The Rise of the Skilled City, w: W. G. Gale (red.), Brookings Wharton Paper on Urban Affairs, J. Rothenberg Pack, 2004, s. 47-94.

${ }^{23}$ L. Briguglio, G. Cordina, S. Bugeja, Conceptualizing and Measuring Economic Resilience, Mimeo, Department of Economics, University of Malta, 2006.

${ }^{24}$ R. Duval, J. Elmeskov, L. Vogel, Structural Policies and Economic Resilience to Shocks, Economics Department Working Paper 567, Organisation for Economic Cooperation and Development, Paris 2007.

${ }^{25}$ J. Feyrer, B. Sacerdote, A. D. Stern, Did the Rustbelt Become Shiny? A Study of Cities and Counties that Lost Steel and Auto Jobs in the 1980s, w: G. Burtless (red.), Brookings Wharton Paper on Urban Affairs, J. Rothenberg Pack, 2007, s. 41-102.

${ }^{26}$ S. Christopherson, J. Clark, Power in Firm Networks: What it Mean for Regional Innovation Systems, „Regional Studies” 49, 2007, s. 1223-1236.

${ }^{27}$ N. Nunn, The Importance of History for Economic Development, NBER Working Paper 14899, National Bureau of Economic Research, Cambridge, MA, 2009.

${ }^{28}$ K. Desmet, E. Rossi-Hansberg, Spatial Growth and Industry Age, „Journal of Economics Theory" 144, 2009, s. 2477-2502. 
wprowadzać nowe produkty lub usługi lub też wykorzystywać nowe technologie do produkcji tego rodzaju dóbr;

- Gersta ${ }^{29}$, który prowadził badania nad różnorodnymi ścieżkami rozwoju w centrach IT zlokalizowanych w miastach Stanów Zjednoczonych (po kryzysie wywołanym pęknięciem bańki spekulacyjnej w sektorze IT w 2000 r.). Gerst zauważa, że wpływ zapaści gospodarczej i ścieżki regeneracji różnią się znacząco, pokazując tym samym odmienny poziom prężności miast. Centra IT specjalizujące się w usługach wychodziły z zapaści o wiele szybciej niż te specjalizujące się w wytwórczości, głównie z powodu lepiej wykwalifikowanych pracowników. Niektóre z centrów IT, pomimo zapaści gospodarczej w sektorze, utrzymały nawet wzrost, głównie z powodu ich szybkiego dostosowania do zmieniającego się popytu;

- Kolko i Neumarka ${ }^{30}$, którzy prowadzili badania nad szokami gospodarczymi i ich wpływem na poziom zatrudnienia $\mathrm{w}$ regionie oraz $\mathrm{w}$ branżach przemysłowych. Zgodnie z ich wynikami poziom zatrudnienia w mniejszym stopniu podlega obniżeniu w łańcuchach firm lokalnych (tj. należących do lokalnego biznesu).

Nawiązanie bezpośrednie do kategorii ekonomicznej prężności miejskiej można odnaleźć także w pracach Hilla, które związane były z obszarami metropolitalnymi Stanów Zjednoczonych ${ }^{31}$. Zgodnie z ich wynikami miasta, które doświadczyły szoku w zakresie spadku zatrudnienia, odzyskują stopę zatrudnienia sprzed szoku, ale nie poziom zatrudnienia, w ciagu około ośmiu lat ${ }^{32}$. Struktura przemysłowa obszarów metropolitalnych wpływa na prawdopodobieństwo kryzysu w regionie, przy czym w przypadku dojrzałych przemysłów prawdopodobieństwo to jest wyższe. Przemysły związane z wytwarzaniem dóbr trwałych są bardziej podatne na zapaść ekonomiczna, głównie ze względu na cykliczność popytu na tego rodzaju dobra. Powoduje to równocześnie większą wrażliwość zatrudnienia w tych sektorach na szoki ekonomiczne. Miasta o takiej strukturze gospodarczej odzyskuja prężność w przypadku ponownego wzrostu popytu.

\section{ATRYBUTY I CZYNNIKI PRĘŻNOŚCI ORAZ WRAŻLIWOŚCI MIEJSKIEJ}

Zdaniem Langa większość obecnych badań nad prężnością miejską wykorzystuje założenie oparte na podejściu systemowym do weryfikacji prężności i wrażliwości ${ }^{33}$. Oznacza to, że miasto jest ujmowane jako kompleksowy, wielowymiarowy system posiadający zdolności adaptacyjne ${ }^{34}$. Zatem w kate-

${ }^{29}$ J. Gerst, M. Doms, M. C. Daly, op. cit.

${ }^{30}$ J. Kolko, D. Neumark, Does Local Business Ownership Insulate Cities from Economic Shocks?, „Journal of Urban Economics” 67, 2010, s. 103-115.

${ }^{31}$ E. Hill, T. Clair, H. Wial et al., op. cit.

${ }^{32}$ Ibidem.

${ }^{33}$ T. Lang, Urban Resilience and New Institutional Theory - A Happy Couple for Urban and Regional Studies?, German Annual of Spatial Research and Policy 2010, Berlin-Heidelberg 2011.

${ }^{34}$ Ibidem. 
goriach prężności tego rodzaju system posiada charakterystyki, atrybuty przypisane strukturom pozwalające na zmaganie się z zewnętrznymi zakłóceniami ${ }^{35}$. Taşan, Stead i Lu argumentuja, że za każdym razem, kiedy system doświadcza zakłóceń, staje się bardziej prężny i w ten sposób prężność jest bezpośrednio związana z adaptacyjnościa do zmian ${ }^{36}$. Natomiast Wardekker podkreśla, że system prężny toleruje zakłócenia zewnętrzne poprzez określone atrybuty, które ograniczają ich wpływ, redukując powstałe szkody. Atrybuty te pozwalają równocześnie systemowi na odpowiedź i szybkie adaptowanie się do zakłóceń generowanych przez otoczenie ${ }^{37}$.

Według Godschalka ${ }^{38}$, Kleina ${ }^{39}$, Walkera i Salta ${ }^{40}$ istnieją specyficzne atrybuty determinujące poziom prężności systemu, a także jego wrażliwości. Atrybuty tego rodzaju moga być wykorzystane w procesie pomiaru i oceny prężności oraz wrażliwości miejskiej. Do atrybutów określających prężność miejską zalicza się: nadmiarowość (redundancy), różnorodność (diversity), efektywność (efficiency), autonomię (autonomy), adaptacyjność (adaptability), współpracę (collaboration), współzależność (interdependence). Jak zauważają Godschalk ${ }^{41}$ oraz Fleischhauer ${ }^{42}$, od miasta prężnego oczekuje się zdolności do adaptacji w warunkach niepewności - zdolność rozumianą w kategoriach pożądanej kombinacji wyżej wskazanych atrybutów.

Założenia związane z postrzeganiem miasta jako systemu kompleksowego wraz z atrybutami prężności i wrażliwości są interesujące poznawczo z punktu widzenia konstruowania metod oceny prężności miejskiej w kategoriach monitoringu i diagnozy strategicznej. Z jednej strony odnoszą się do holistycznego spojrzenia na miasto (system kompleksowy), z drugiej zaś pozwalają na zdekomponowanie systemu miejskiego na atrybuty, które mogą być w dalszej kolejności opisywane przez czynniki prężności i wrażliwości, a następnie przez korespondujące z nimi wskaźniki ilościowe i jakościowe ${ }^{43}$.

${ }^{35}$ I. Folke et al., Resilience and Sustainable Development: Building Adaptive Capacity in a World of Transformations, Environmental Advisory Council to the Swedish Government, „Ambio" 31, 2002, nr 5 .

${ }^{36}$ K. Taşan-Kok, D. Stead, P. Lu, Conceptual Overview of Resilience: History and Context, w: A. Eraydin, T. Taşan-Kok (red.), Resilience Thinking in Urban Planning, Springer, Dordrecht 2013.

${ }^{37}$ A. J. Wardekker et al., Operationalising the Resilience Approach to Adapting an Urban Delta to Uncertain Climate Changes, „Technological Forecasting and Social Change” 77, 2010, nr 7.

${ }^{38}$ D. R. Godschalk, Urban Hazard Mitigation: Creating Resilient Cities, „Natural Hazards Review" 4, 2003, nr 3.

${ }^{39}$ R. J. T. Klein et al., Resilience to Natural Hazards. How Useful Is the Concept?, „Environmental Hazards" 5, 2003, nr 1/2.

${ }^{40}$ B. Walker, D. Salt, op. cit.

${ }^{41}$ D. R. Godschalk, op. cit.

${ }^{42}$ M. Fleischhauer, The Role of Spatial Planning and Strengthening Urban Resilience, w: H. J. Pasman, I. A. Krillov (red.), Resilience of Cities to Terrorists and Other Threats. Learning from 9/11 and Further Research Issues, Springer, Dordrecht 2008.

${ }^{43}$ F. Berkes et al., Navigating Social-ecological Systems. Building Resilience for Complexity and Change, CUP, Cambridge 2003. 
Reasumując powyższe rozważania, prężność miasta jako systemu kompleksowego może być determinowana przez kombinację następujących atrybutów prężności: adaptacyjność, połączalność, różnorodność, efektywność, nadmiarowość, współzależność. Poszczególne kategorie atrybutów prężności miejskiej zostały zdefiniowane w tabeli 1 . Ich wysoka wartość wywiera pozytywny wpływ na poziom prężności miasta. Zakładając, że atrybuty wrażliwości miejskiej moga zostać zdefiniowane przez „opozycję” do atrybutów prężności, ich zbiór jest następujący: niedostosowanie, fragmentaryzacja, nadmierna specjalizacja, nieefektywność, niedomiar, niezgodność (por. tab. 1). Wysoka wartość atrybutów wrażliwości będzie świadczyła o dużej ekspozycji miasta na zakłócenia generowane przez otoczenie.

\section{Tabela 1}

Atrybuty prężności i wrażliwości miejskiej

\begin{tabular}{|c|c|}
\hline Wrażliwość & Prężność \\
\hline $\begin{array}{l}\text { Ni e do s to sow a n i e - struktury miasta nie } \\
\text { posiadają zdolności do zmiany lub przystoso- } \\
\text { wania się do warunków otoczenia (inercja) }\end{array}$ & $\begin{array}{l}\text { Ad a p ta cyj n ość - struktury miasta posia- } \\
\text { dają zdolność do zmiany i/lub dopasowania } \\
\text { się do zmieniajacych się warunków otoczenia, } \\
\text { są elastyczne }\end{array}$ \\
\hline $\begin{array}{l}\text { F r a g m e n t a r y z a cj a - struktury miasta } \\
\text { sa rozdzielone na mniejsze, niepołaczone } \\
\text { elementy }\end{array}$ & $\begin{array}{l}\text { Połą z a lność - struktury miejskie posia- } \\
\text { dają zdolność kreowania powiązań }\end{array}$ \\
\hline $\begin{array}{l}\text { Nadmierna specjalizacja-struktury } \\
\text { miasta cechuje nadmierna zdolność adapta- } \\
\text { cyjna, ale podporzadkowana tylko jednemu } \\
\text { specyficznemu celowi (np. sektorowi) }\end{array}$ & $\begin{array}{l}\text { Ró ż n o r o d n o ść - struktury miejskie po- } \\
\text { siadają wyraźną heterogeniczność, są zróżni- } \\
\text { cowane }\end{array}$ \\
\hline $\begin{array}{l}\text { Ni e efe k ty w n o ść - struktury miasta nie } \\
\text { zapewniaja pożądanych rezultatów w relacji } \\
\text { do nakładów }\end{array}$ & $\begin{array}{l}\text { E fekty w ność - struktury miasta zapew- } \\
\text { niaja pozytywną relację pomiędzy wynikami } \\
\text { a nakładami w całym systemie i/lub posiadają } \\
\text { zdolność unikania strat }\end{array}$ \\
\hline $\begin{array}{l}\text { Ni e w y s ta rcza ln ość/n i ed omiar } \\
\text { - struktury miasta (lub ich elementy) nie } \\
\text { funkcjonuja normalnie (sa niewystarczalne) } \\
\text { w sytuacji defektu systemu }\end{array}$ & $\begin{array}{l}\text { Red u n d a n cja / n a d mi a row ość - struk- } \\
\text { tury miasta posiadaja zdolność zapewniania } \\
\text { dodatkowych elementów systemu na wypadek } \\
\text { jego zanikania, defektu }\end{array}$ \\
\hline $\begin{array}{l}\text { Ni e z g o d no śćldy s o n a n s-struktury } \\
\text { miasta wraz z niezależnymi ich elementami } \\
\text { cechuje brak współdziałania generującego } \\
\text { korzyści }\end{array}$ & $\begin{array}{l}\text { W s pół z a le ż ność - struktury miasta } \\
\text { kreują relacje pomiędzy niezależnymi ele- } \\
\text { mentami systemu, które przynoszą wzajemne } \\
\text { korzyści }\end{array}$ \\
\hline
\end{tabular}

Źródło: opracowano na podstawie D. R. Godschalk, op. cit.; R. J. T. Klein et al., op. cit.; B. Walker, D. Salt, op. cit.

$\mathrm{Z}$ punktu widzenia monitoringu i diagnozy strategicznej miasta niezbędna jest dalsza dekompozycja atrybutów prężności i wrażliwości na czynniki determinujące ich wartość. W dekompozycji tego rodzaju moż- 
na posłużyć się m.in. badaniami prowadzonymi przez: Briguglia ${ }^{44}$, Lansforda ${ }^{45}$, Hessa ${ }^{46}$, Cooke'a ${ }^{47}$, Wolfa ${ }^{48}$, Lazzeretti i Parrillego ${ }^{49}$, Melkasa i Uotila ${ }^{50}$ (por. tab. 2 i 3).

\section{Tabela 2}

Propozycje czynników prężności miejskiej w wymiarze ekonomicznym

\begin{tabular}{|c|c|}
\hline Atrybuty prężności & $\begin{array}{l}\text { Czynniki prężności miejskiej w wymiarze ekonomicznym } \\
\text { (propozycje) }\end{array}$ \\
\hline Adaptacyjność & $\begin{array}{l}\text { - } \text { wysoki poziom przedsiębiorczości } \\
\text { - } \text { znaczące zdolności do innowacji } \\
\text { - } \text { istotne lokalne zasoby wiedzy (baza wiedzy, infrastruktura badaw- } \\
\text { cza, transfer wiedzy) } \\
\text { - duże zasoby ekonomiczne (liczba przedsiębiorstw, wartość ich akty- } \\
\text { wów, przychody) }\end{array}$ \\
\hline Połączalność & $\begin{array}{l}\text { - aktywne sieci aktorów gospodarczych (powiązania klastrowe w łań- } \\
\text { cuchach produkcji i dystrybucji) } \\
\text { - międzysektorowe powiazania w zakresie wiedzy (platformy innowa- } \\
\text { cji i komercjalizacji w ramach różnych łańcuchów produkcji, efekty } \\
\text { „rozsiewu”) }\end{array}$ \\
\hline Różnorodność & - zróżnicowana specjalizacja gospodarcza (industrial mix) \\
\hline Efektywność & $\begin{array}{l}\text { - } \text { ponadlokalna konkurencyjność produktów } \\
\text { - } \text { wysoka wartość dodana łańcuchów produkcji (opłacalność poszcze- } \\
\text { gólnych ogniw łańcuchów produkcji, gałęzie przemysłu oparte na } \\
\text { wiedzy) } \\
\text { - }\end{array}$ \\
\hline Redundancja & $\begin{array}{l}\text { - różnorodne, trwałe i niezawodne źródła energii } \\
\text { - dodatkowe, bezpieczne aplikacje ICT } \\
\end{array}$ \\
\hline Współzależność & $\begin{array}{l}\text { - dobre praktyki i standardy w zakresie współpracy gospodarczej } \\
\text { - komplementarność lokalnych przemysłów (w tym efekty aglomera- } \\
\text { cji) }\end{array}$ \\
\hline
\end{tabular}

Źródło: opracowano na podstawie L. Briguglio et al., op. cit.; T. Lansford et al., op. cit.; D. Hess, op. cit.; Ph. Cooke, op. cit.

${ }^{44}$ L. Briguglio et al., Economic Vulnerability and Resilience: Concepts and Measurements, Research Paper No. 55, United Nation University, Geneva 2008.

${ }^{45}$ T. Lansford et al., Fostering Community Resilience. Homeland Security and Hurrican Katrina, Ashgate, Farnham 2010.

${ }^{46}$ D. Hess, Sustainable Consumption, Energy and Failed Transitions: The Problem of Adaptation, w: M. J. Cohen et al. (red.), Innovations in Sustainable Consumption. New Economies, Socio-technical Transitions and Social Practices, Edwartd Elgar Publishing, Cheltenham 2013.

${ }^{47} \mathrm{Ph}$. Cooke, Regional Innovation Systems, Clean Technology and Jacobian Cluster-platform Policies, „Regional Sciences, Policy and Practice” 1, 2008, nr 1, 23-45.

${ }^{48}$ D. A. Wolfe, Resilience and Growth in Canadian City-regions, w: Ph. Cooke (red.), Re-framing Regional Development. Evolution, Innovation and Transition, Routledge, London 2013.

${ }^{49}$ L. Lazzeretti, M. D. Parrilli, New Focus on Economic Reactivation in Spain: Creative Industries in the Basque Country, w: Ph. Cooke, M. D. Parrilli, J. L. Curbelo (red.), Innovation, Global Change and Territorial Resilience, Edward Elgar, Cheltenham 2012.

${ }^{50}$ H. Melkas, T. Uotila, Foresight and Innovation. Emergence and Resilience of the Cleantech Cluster at Lahti, Finland, w: Ph. Cooke, op. cit. 
Przykładowo, w zakresie atrybutu adaptacyjności jego wartość może być determinowana wysokim poziomem przedsiębiorczości oraz znaczącymi zdolnościami do innowacji. Istotne dla analizowanego atrybutu są także lokalne zasoby wiedzy postrzegane m.in. w kategoriach bazy wiedzy czy lokalnej infrastruktury badawczej.

Tabela 3

Propozycje czynników wrażliwości miejskiej w wymiarze ekonomicznym

\begin{tabular}{|c|c|}
\hline Atrybuty wrażliwości & Czynniki wrażliwości miejskiej w wymiarze ekonomicznym (propozycje) \\
\hline Niedostosowanie & $\begin{array}{ll}\text { - } & \text { bierność ekonomiczna (brak aktywności przedsiębiorczej) } \\
\text { - } & \text { nieskuteczność restrukturyzacji } \\
\text { - } & \text { pasywne nastawienie do zmian (,próżnia innowacji”) } \\
\text { - } & \text { niedostatek lokalnych zasobów wiedzy (słaba baza wiedzy i/lub brak } \\
& \text { infrastruktury badawczej) }\end{array}$ \\
\hline Fragmentaryzacja & $\begin{array}{l}\text { - } \begin{array}{l}\text { rozłączność aktorów gospodarczych (,zatomizowana” produkcja i dys- } \\
\text { trybucja) } \\
\text { - przerwane powiązania w zakresie transferu wiedzy (nadmierna } \\
\text { ochrona zasobów wiedzy i ich separacja) }\end{array} \\
\end{array}$ \\
\hline $\begin{array}{l}\text { Nadmierna specja- } \\
\text { lizacja }\end{array}$ & - pojedyncza specjalizacja przemysłowa (industrial single) \\
\hline Nieefektywność & 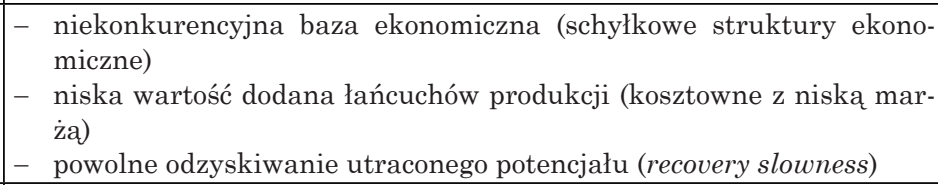 \\
\hline $\begin{array}{l}\text { Niewystarczalnośćl } \\
\text { niedomiar }\end{array}$ & $\begin{array}{ll}\text { - } & \text { tradycyjne źródła energii (pojedyncze, uciążliwe środowiskowo) } \\
\text { - } & \text { wrażliwe aplikacje ICT (brak stabilnych systemów ICT ) }\end{array}$ \\
\hline $\begin{array}{l}\text { Niezgodność/dyso- } \\
\text { nans }\end{array}$ & $\begin{array}{l}\text { - } \text { destrukcyjne/wyniszczające standardy konkurowania (nadmierna } \\
\text { konkurencja) } \\
\text { - „przypadkowe” przemysły lokalne (niepowiazzane, zatomizowane fir- } \\
\text { my lokalne niezdolne do wytworzenia efektów komplementarności, } \\
\text { koopetycji) }\end{array}$ \\
\hline
\end{tabular}

Źródło: opracowano na podstawie: Ph. Cooke, op. cit.; D. A. Wolfe, op. cit.; L. Lazzeretti, M. D. Parrilli, op. cit.; H. Melkas, T. Uotila, op. cit.

Przykładowe czynniki dla atrybutu wrażliwości miejskiej, związanego z niezgodnościa, mogą odnosić się do destrukcyjnych, wyniszczających standardów konkurowania prowadzących do nadmiernego natężenia konkurencji. Wartość atrybut niezgodności tworzona jest także przez takie charakterystyki lokalnej struktury gospodarczej, jak „przypadkowe” ${ }^{51}$ przemysły zlokalizowane w danym mieście, które tworzone są przez zatomizowane przedsiębiorstwa. Niski poziom współzależności firm prowadzi m.in. do braku lokalnych powiązań gospodarczych, słabych efektów ekonomicznych wynikających z komplementarności oraz koopetycji.

51 „Przypadkowe”, w rozumieniu niezwiązane z lokalnymi potencjałami społeczno-gospodarczymi, często firmy zewnętrzne bazujące wyłącznie na przewadze kosztów jednostkowych zasobów ludzkich lub też dostępie do rynku zbytu. 


\section{DIAGNOZA PRĘ̇̇NOŚCI MIEJSKIEJ W WYBRANYCH MIASTACH POLSKI}

\section{Założenia metodyczne}

Wstępna ocena prężności miejskiej w wymiarze ekonomicznym została przeprowadzona w podejściu ilościowym. W tym celu ocenę prężności oparto na popularnych wskaźnikach dynamiki o stałej podstawie, opisujących główne parametry rozwoju miasta $\mathrm{w}$ powiązaniu $\mathrm{z}$ atrybutami prężności i wrażliwości. Za okres porównawczy diagnozy wybrano lata 1995-2012, tj. horyzont, w którym badane miasta podlegały różnorodnym wpływom otoczenia, zarówno pozytywnym, jak i negatywnym. Podczas dekomponowania atrybutów i czynników prężności miejskiej w kontekście ekonomicznym, posłużono się następującymi założeniami:

1) dla atrybutu adaptacyjności dobrano czynnik związany z wysoką przedsiębiorczościa, który został zdiagnozowany za pomocą wskaźników:

a) dynamika liczby osób fizycznych prowadzących działalność gospodarczą na 1000 mieszkańców,

b) dynamika liczby podmiotów gospodarczych na 1000 mieszkańców,

2) dla atrybutu nadmiarowości dobrano czynnik związany ze stabilnością miejsc pracy mierzony za pomocą wskaźnika: dynamika liczby zatrudnionych na 1000 mieszkańców,

3) dla atrybutu efektywności posłużono się czynnikiem finansowej siły przedsiębiorstw, diagnozowanym za pomocą wskaźnika: dynamika przychodów do budżetu miasta z tytułu podatku CIT. W przypadku tego wskaźnika posłużono się wartościa realną wpływów liczoną dla roku bazowego, tj. 1995.

W przypadku dekompozycji czynników i wskaźników wrażliwości miejskiej odnoszonych do wymiaru ekonomicznego wykorzystano następujące założenia:

1) dla atrybutu niedostosowania i czynnika bierności ekonomicznej zastosowano wskaźnik odnoszący się do:

a) dynamiki liczby bezrobotnych na 1000 mieszkańców,

b) dynamiki udziału zatrudnionych $\mathrm{w}$ warunkach szkodliwych. Wskaźnik ten może być postrzegany jako odzwierciedlenie udziału przemysłów tradycyjnych w strukturze gospodarczej miast,

c) dynamiki bezrobotnych bez doświadczenia zawodowego jako procent bezrobotnych ogółem,

2) dla atrybutu nieefektywności i związanego z nim czynnika braku konkurencyjności bazy ekonomicznej miasta wybrano wskaźnik: dynamika udziału bezrobotnych zwolnionych z przyczyn zakładu pracy.

Dobór wskazanych wskaźników był determinowany z jednej strony ich logiczną zależnością względem atrybutów i czynników związanych z prężnością i wrażliwością miejską w wymiarze ekonomicznym, z drugiej zaś - został silnie ograniczony przez dostępność długookresowych danych sta- 
tystycznych. Kalkulacje wszystkich wskaźników dynamiki zostały oparte na założeniach stosowanych w badaniach Hilla ${ }^{52}$.

Diagnoza prężności i wrażliwości miejskiej została przeprowadzona dla następujacych krajowych jednostek terytorialnych: Kraków, Poznań, Wrocław oraz Aglomeracja Górnoślaska (badana łącznie jako zbiór 14 miast na prawach powiatu). Dobór miał charakter celowy, tj. umożliwiający porównanie wybranych dużych miast Polski, które nie posiadają tak dużego dziedzictwa przemysłowego, z miastami poprzemysłowymi Aglomeracji Górnośląskiej, której rodowód przemysłowy jest znaczący. Zamierzeniem takiego porównania było z jednej strony zbadanie, w jakim stopniu zmiany otoczenia wpływają na dynamikę rozwoju miast o odmiennym rodowodzie społeczno-gospodarczym w kategoriach prężności i wrażliwości. Z drugiej zaś - służyło kompleksowej weryfikacji zaproponowanej metodyki badawczej oceny prężności miejskiej.

Syntetycznym podsumowaniem analiz są trajektorie prężności miast ${ }^{53}$ wraz z wyznaczeniem ich typologii determinowanej stopniem wpływu zakłóceń zewnętrznych na badane atrybuty ekonomicznej prężności i wrażliwości.

\section{Wyniki badań}

W zakresie prężności miejskiej, analizowanej za pomoca dynamiki odnoszącej się do liczby firm prowadzonych przez osoby fizyczne, największą prężność wykazuje Kraków. Dynamika wzrostu firm prowadzonych przez osoby fizyczne w tym mieście w 2012 r. osiagnęła poziom ok. $170 \mathrm{w}$ relacji do roku bazowego. Na drugim miejscu uplasował się Poznań z wartością ok. 150 w relacji do roku bazowego. Najniższa dynamika liczby firm osób fizycznych notowana jest natomiast dla Aglomeracji Górnoślaskiej, tj. ok. 140 w relacji do roku bazowego. Należy zwrócić uwagę, że począwszy od 2003 r., dynamika liczby firm prowadzonych przez osoby fizyczne w przypadku Aglomeracji Górnoślasskiej wykazuje trend horyzontalny (z wyjątkiem 2010 r.) por. wykres 1 .

Badane jednostki samorządu terytorialnego cechuje względnie stały trend wzrostowy, jeśli wziąc pod uwagę dynamikę liczby podmiotów gospodarczych. Najszybciej tak rozumiany potencjał gospodarczy powiększa się w Krakowie, osiagajac poziom niemal $190 \mathrm{w}$ relacji do roku bazowego. Na kolejnych miejscach plasują się Poznań i Wrocław z poziomem dynamiki ok. 170. W przypadku miast poprzemysłowych Aglomeracji Górnoślaskiej dynamika podmiotów gospodarczych ma również charakter pozytywny (ok. $160 \mathrm{w}$ relacji do roku bazowego), aczkolwiek w tym przypadku w okresach 2003-2008 oraz 2010-2012 trend dynamiki ma charakter horyzontalny (por. wykres 2).

52 E. Hill, T. Clair, H. Wial et al., op. cit.

53 A. Drobniak, Factors Determining Urban Resilience, w: idem (red.), Urban Resilience Concept and Post-industrial Cities in Europe, Helion, Gliwice 2014 (w druku). 
Wykres 1

Dynamika wskaźnika liczby firm prowadzonych przez osoby fizyczne w latach 1995-2012 na 1000 mieszkańców

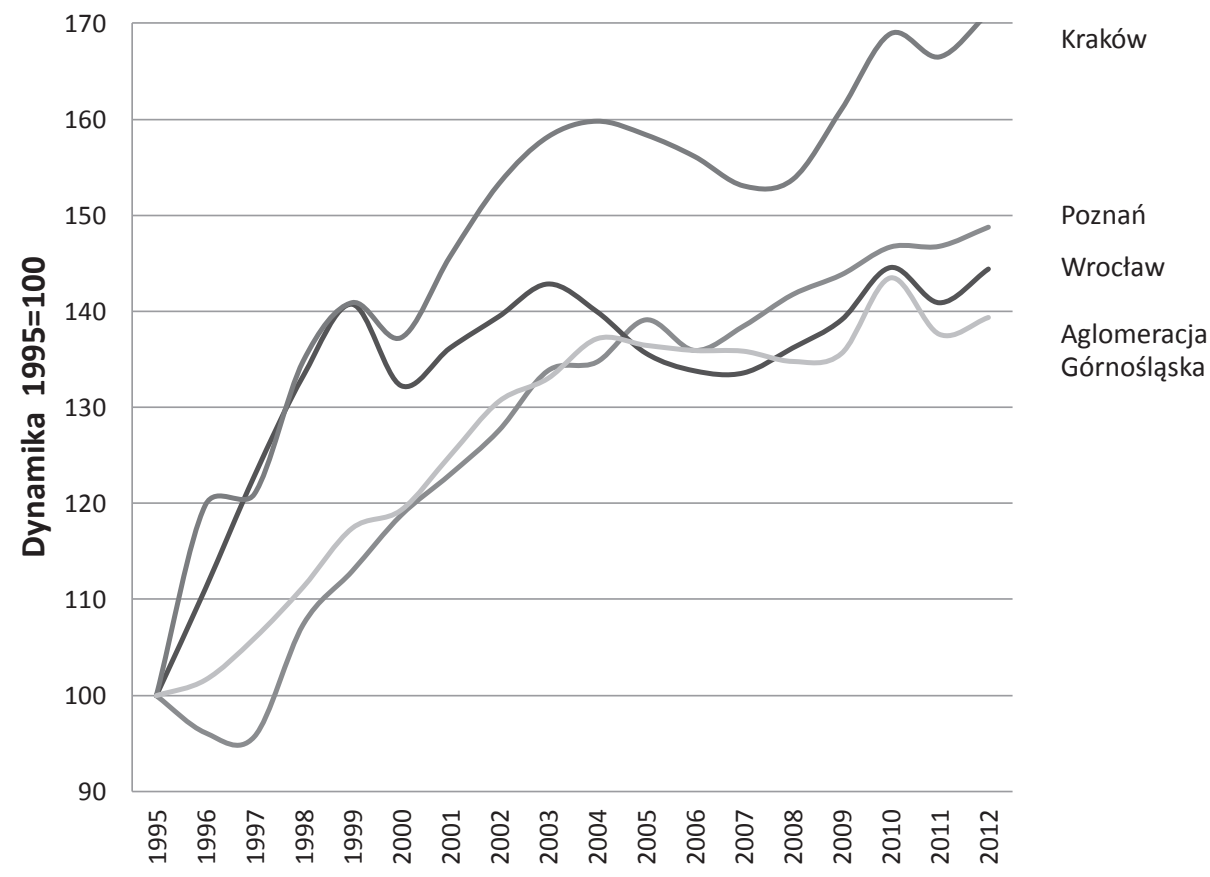

Źródło: opracowanie własne.

Bardziej odmienne charakterystyki prężności analizowanych miast odnoszą się do wskaźnika liczby miejsc pracy na 1000 mieszkańców. Miasta nieposiadajace silnego rodowodu przemysłowego powiększają potencjał miejsc pracy w latach 1995-1999. W kolejnych latach (2000-2003, w których nastapiło osłabienie dynamiki wzrostu gospodarki Polski) w ich przypadku następuje zwrot kierunku dynamiki oznaczający kurczenie się liczby miejsc pracy. W najmniejszym stopniu kurczenie się potencjału miejsc pracy dotyczy Poznania - minimalna wartość wskaźnika dynamiki sięga ok. 95 wartości bazowej. W Krakowie i Wrocławiu wartość minimalna wskaźnika dynamiki plasuje się na poziomie ok. 85. Ostatecznie dynamika liczby miejsc pracy zarówno w Poznaniu, jak i Krakowie oraz Wrocławiu w ostatnim okresie analizy jest wyższa od wartości bazowej, aczkolwiek w odmiennym stopniu. Największą dynamikę dla analizowanego wskaźnika wykazuje Wrocław (ok. 110 wartości bazowej). Na drugim miejscu plasuje się Poznań (ok. 105 wartości bazowej), następnie Kraków (nieco ponad 100 wartości bazowej). 
Wykres 2

Dynamika wskaźnika liczby podmiotów gospodarczych na 1000 mieszkańców w latach 1995-2012

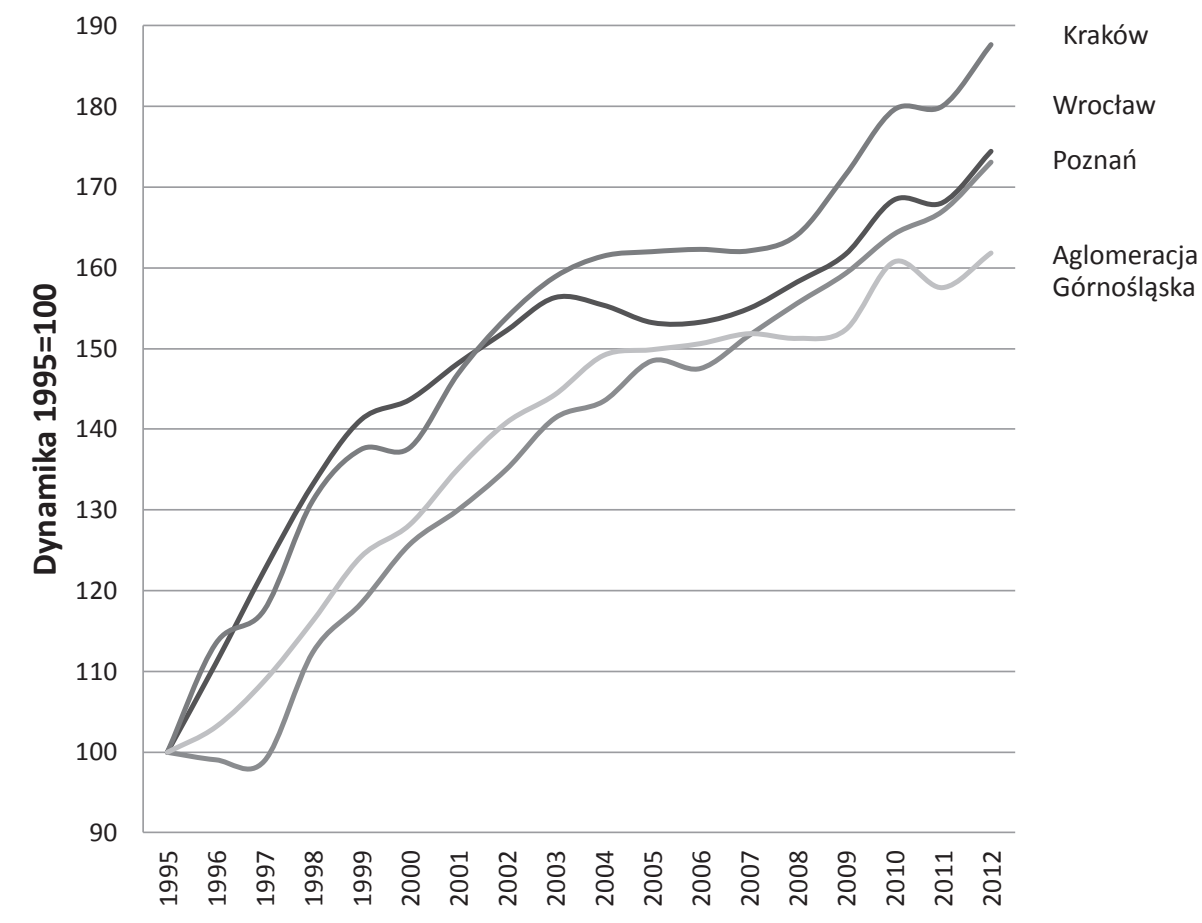

Źródło: opracowanie własne.

Interesujacym badawczo przypadkiem jest dynamika liczby miejsc pracy notowana dla miast Aglomeracji Górnoślaskiej. W latach 1995-2003 dynamika miejsc pracy jest w tym przypadku negatywna i osiaga wartość minimalną w 2003 r. (ok. 77 wartości bazowej). Lata 2004-2008 oznaczają wzrost wartości dynamiki liczby miejsc pracy do poziomu ok. 85 wartości bazowej. Niemniej prawdopodobnie na skutek globalnego kryzysu finansowego, a także stagnacji w tradycyjnych branżach przemysłowych w kolejnych latach badana dynamike cechuje trend horyzontalny. Ostatecznie miasta poprzemysłowe Aglomeracji Górnośląskiej w całym analizowanym okresie nie odzyskują potencjału miejsc pracy z 1995 r. (por. wykres 3), co świadczy o ich wysokiej wrażliwości.

Ostatni z omawianych wskaźników prężności miejskiej w wymiarze ekonomicznym dotyczy siły finansowej przedsiębiorstw zlokalizowanych na terenie danego miasta. Dynamika przychodów z tytułu podatku CIT generalnie w latach 1995-2002 wykazuje wartość negatywną (Poznań i Wrocław poziom ok. 80 wartości bazowej, Aglomeracja Górnośląska poziom ok. 60 wartości bazowej, Kraków poziom ok. 40 wartości bazowej). 


\section{Wykres 3}

Dynamika wskaźnika liczby miejsc pracy na 1000 mieszkańców w latach 1995-2012

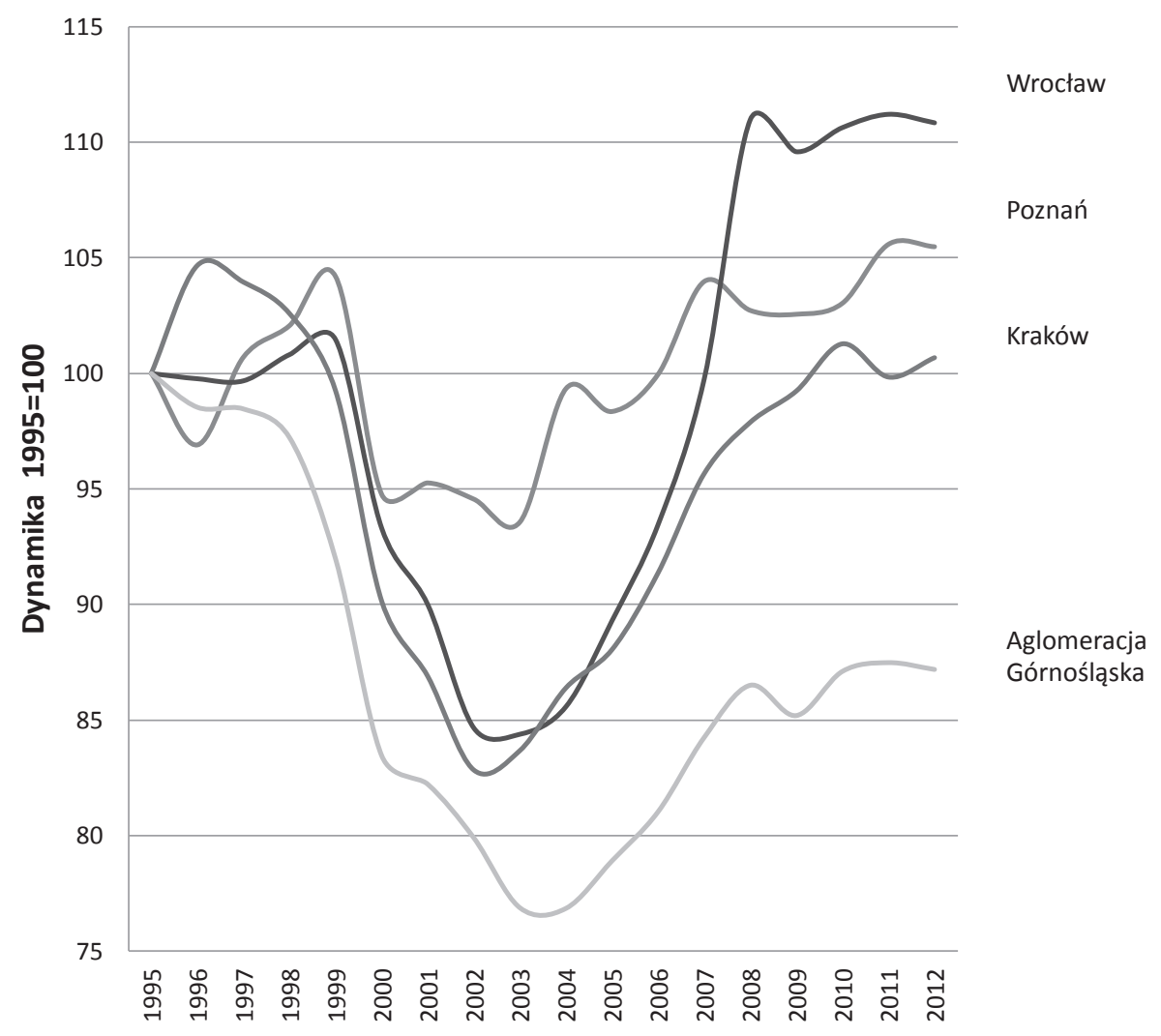

Źródło: opracowanie własne.

Począwszy od 2003 r., w przypadku wszystkich analizowanych miast następuja silne wzrosty dynamiki przychodów podatkowych z tytułu CIT. Wartości maksymalne notowane są dla 2008 r., choć ich wartość dla poszczególnych miast cechuje się dużą odmiennością. Najlepszą kondycję finansowa w 2008 r. posiadały firmy zlokalizowane we Wrocławiu - dynamika przychodów z CIT sięga niemal 360 poziomu z roku bazowego. $\mathrm{Na}$ drugiej pozycji plasują się firmy poznańskie - w ich przypadku dynamika wpływów podatku CIT wynosi ok. 290 wartości bazowej. Wysoka wartość dynamiki wpływów z podatku CIT notowana jest także w Aglomeracji Górnoślaskiej (230 wartości bazowej) oraz Krakowie (ok. 200 wartości bazowej). Po $2008 \mathrm{r}$. we wszystkich analizowanych miastach następuje gwałtowany spadek przychodów z podatku CIT, będący prawdopodobnie 
następstwem światowego kryzysu finansowego. Z wyjątkiem Wrocławia, negatywna dynamika wpływów z podatku CIT nie została wyhamowana nawet w 2012 r. (por. wykres 4).

\section{Wykres 4}

Dynamika wskaźnika przychodów podatkowych do budżetów miast z tytułu podatku CIT w latach 1995-2012

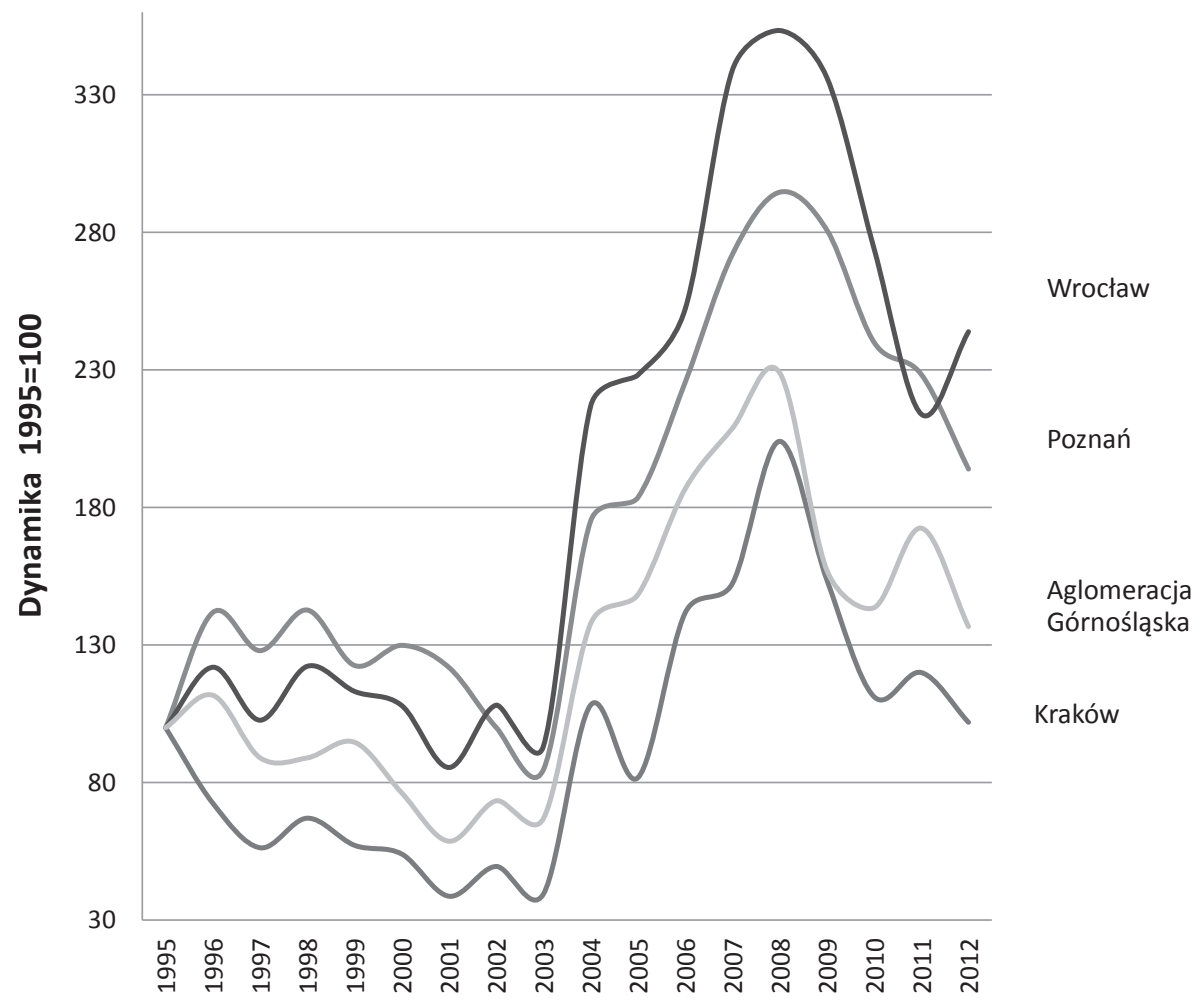

Źródło: opracowanie własne.

Pierwszy z badanych wskaźników wrażliwości ekonomicznej miast wiąże się z dynamiką bezrobotnych ogółem. Dynamika tego wskaźnika dla poszczególnych miast wykazuje duży poziom podobieństwa, niemniej skala zmian w zakresie bezrobocia jest nieco odmienna w każdym z analizowanych przypadków. W relacji do Krakowa, Poznania i Wrocławia miasta Aglomeracji Górnośląskiej cechowały się w latach 1998-2002 zdecydowanie większymi przyrostami bezrobocia w przeliczeniu na 1000 mieszkańców. Było to niewatpliwie spowodowane przebiegiem procesów restrukturyzacji przemysłu tradycyjnego, na które dodatkowo nałożyła się słaba koniunktura gospodarcza w kraju (por. wykres 5). 


\section{Wykres 5}

Dynamika wskaźnika bezrobotni na 1000 mieszkańców w latach 1998-2012

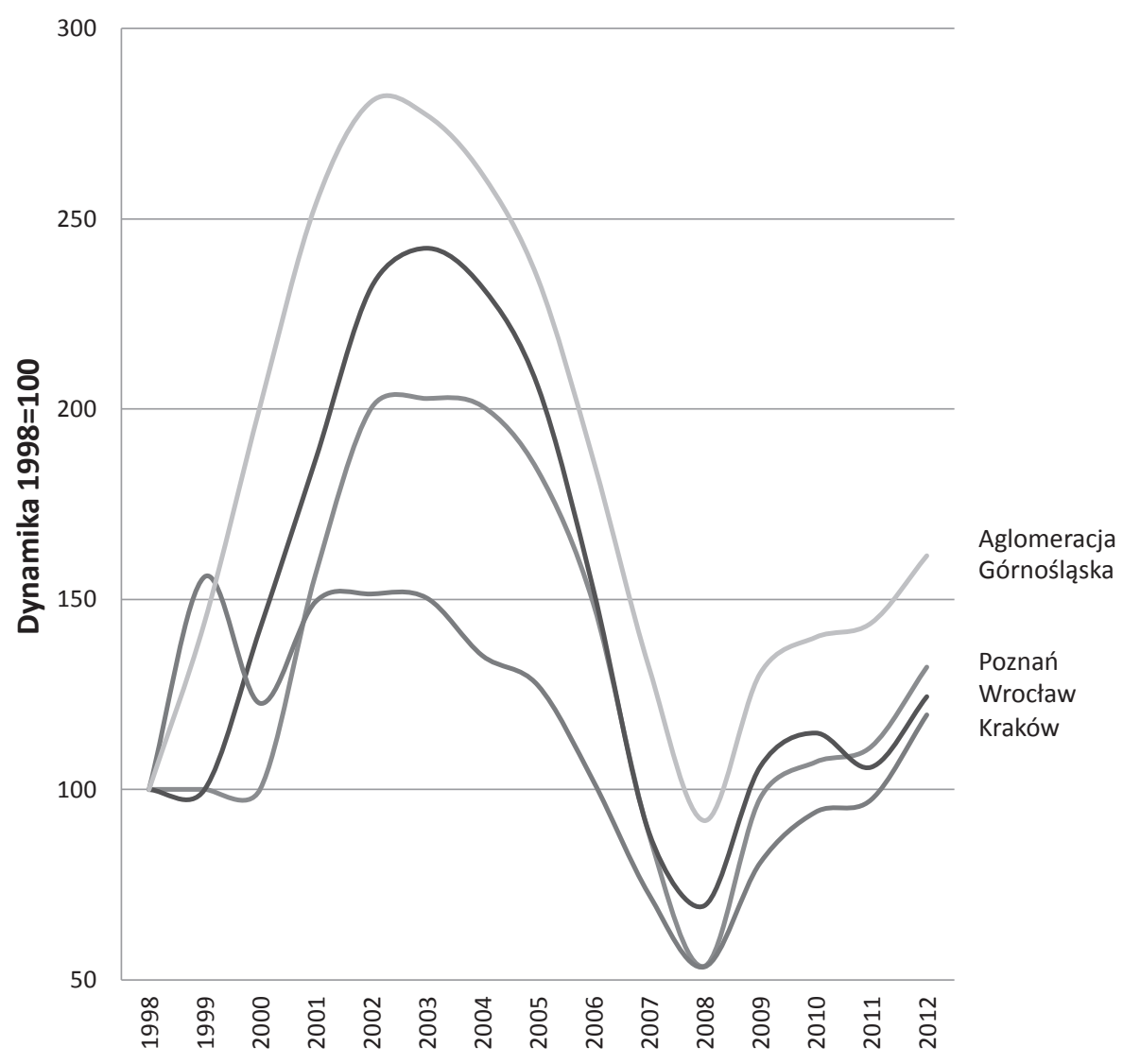

Źródło: opracowanie własne.

Począwszy od 2002 r., we wszystkich analizowanych miastach nastapiło zmniejszenie poziomu bezrobocia. Spadek ten został zatrzymany w 2008 r., choć w najmniejszym stopniu w Aglomeracji Górnośląskiej. Ogólnoświatowy kryzys finansowy spowodował także w miastach Aglomeracji Górnośląskiej silniejszy niż we Wrocławiu, Poznaniu i Krakowie wzrost poziomu bezrobocia w latach 2009-2012 (por. wykres 5).

Wrażliwości gospodarek Krakowa, Poznania, Wrocławia i miast Aglomeracji Górnoślasskiej mierzona za pomoca dynamiki udziału zatrudnionych w warunkach szkodliwych w ogóle zatrudnionych (por. wykres 6) wskazuje, że we wszystkich badanych ośrodkach miejskich w latach 2000-2012 następuje zmniejszenie liczby tego rodzaju miejsc pracy. Przemawia to za unowocześnia- 
niem procesów przetwórstwa przemysłowego, jakie dokonuje się w ostatniej dekadzie, a także likwidacją przemysłów tradycyjnych, jaka ma miejsce w miastach Aglomeracji Górnoślaskiej. Najszybciej tego rodzaju procesy przebiegaja w Krakowie i Wrocławiu. Warto jednak zauważyć, że w przypadku Poznania dynamika zatrudnienia w warunkach szkodliwych jest najniższa w relacji do pozostałych jednostek terytorialnych, a w ostatnich latach (2009-2012) przyjmuje trend horyzontalny, co przemawia za utrzymywaniem się tego rodzaju miejsc pracy w gospodarce miasta (por. wykres 6).

\section{Wykres 6}

Dynamika wskaźnika udziału zatrudnionych w warunkach szkodliwych w latach 2000-2012

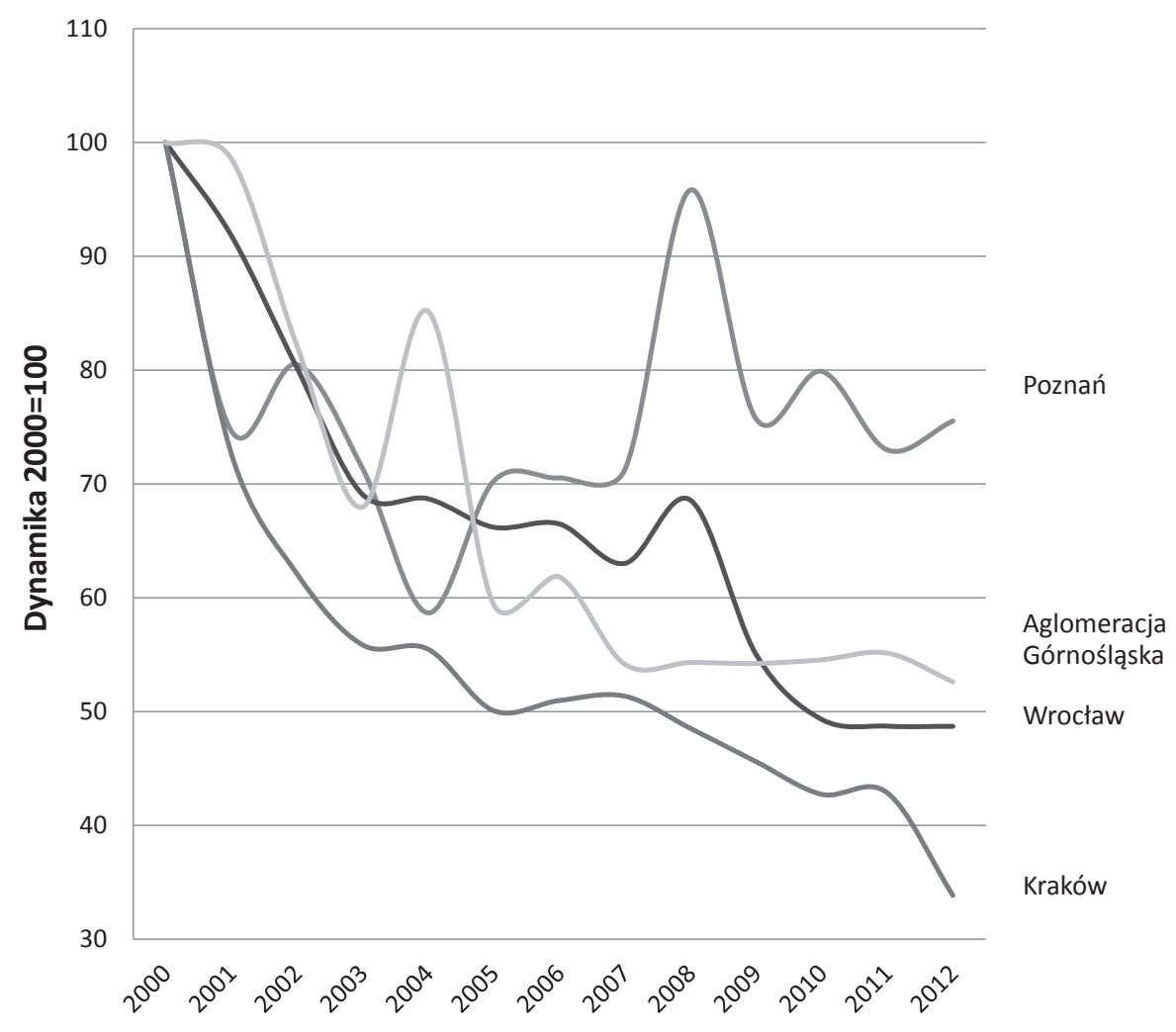

Źródło: opracowanie własne.

Następny ze wskaźników wrażliwości miejskiej odnosi się do dynamiki udziału bezrobotnych bez doświadczenia w ogóle bezrobotnych (por. wykres 7). $\mathrm{W}$ perspektywie do $2012 \mathrm{r}$. we wszystkich ośrodkach miejskich udział tego rodzaju bezrobotnych zmniejszał się. Największy spadek odnotowano jednak 


\section{Wykres 7}

Dynamika wskaźnika udziału bezrobotnych bez doświadczenia w ogóle bezrobotnych w latach 2000-2012

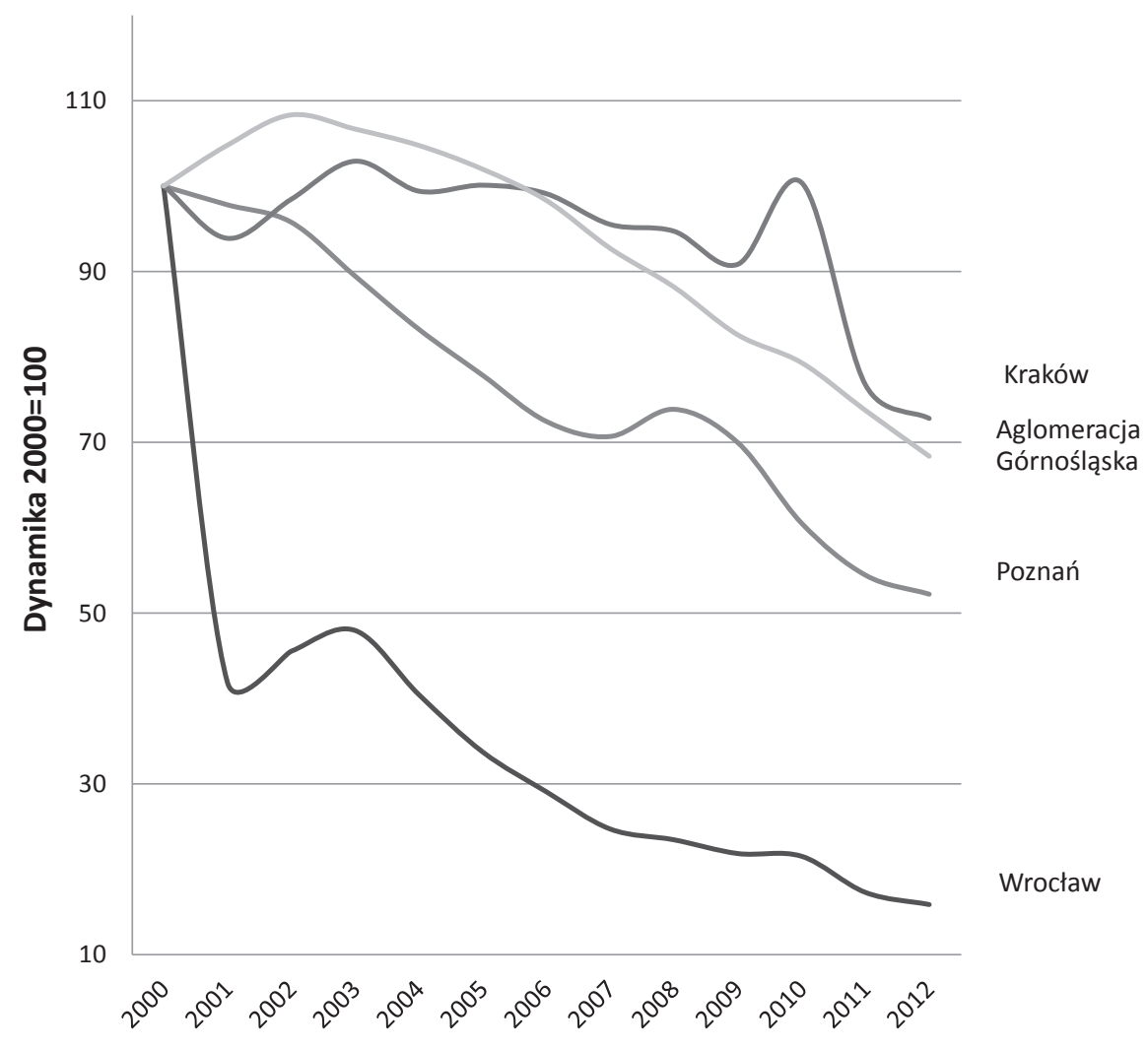

Źródło: opracowanie własne.

we Wrocławiu (poziom ok. 15 wartości bazowej z 2000 r.), następnie zaś w Poznaniu (poziom ok. 50 wartości bazowej). Natomiast w przypadku Aglomeracji Górnoślasskiej i Krakowa dynamika udziału bezrobotnych bez doświadczenia w ogóle bezrobotnych w 2012 r. ukształtowała się na poziomie ok. 70 wartości bazowej.

Poznawczo interesujących wniosków na temat wrażliwości ekonomicznej badanych miast dostarcza także analiza wskaźnika dynamiki odnoszonej do udziału bezrobotnych zwolnionych z przyczyn zakładu pracy (por. wykres 8). Tego rodzaju wskaźnik sygnalizuje m.in., w jaki sposób przedsiębiorstwa podchodzą do wielkości zatrudnienia w sytuacji kryzysu lub też w warunkach prosperity. Do 2008 r., tj. początku światowego kryzysu finansowego, zarówno w Aglomeracji Górnoślaskiej, jak i Poznaniu oraz Krakowie dynamika tego ro- 
dzaju zwolnień z pracy maleje, choć w różnym stopniu. W tej grupie jednostek samorządu terytorialnego najniższą wartość dynamiki zwolnień odnotowano w Aglomeracji Górnoślaskiej (ok. 25 wartości bazowej), następnie w Krakowie (ok. 47 wartości bazowej) oraz Poznaniu (ok. 50 wartości bazowej). Ciekawy jest natomiast przypadek Wrocławia, w którym poziom dynamiki zwolnień z przyczyn zakładu pracy spadał nawet po początkowej fazie światowego kryzysu finansowego, tj. do 2010 r. (ok. 15 wartości bazowej). W następnych latach firmy wrocławskie cechował znaczący wzrost zwolnień z przyczyn leżących po stronie pracodawców do poziomu ok. 60 wartości bazowej.

\section{Wykres 8}

Dynamika wskaźnika udziału bezrobotnych zwolnionych z przyczyn po stronie przedsiębiorstwa w ogóle bezrobotnych w latach 2000-2012

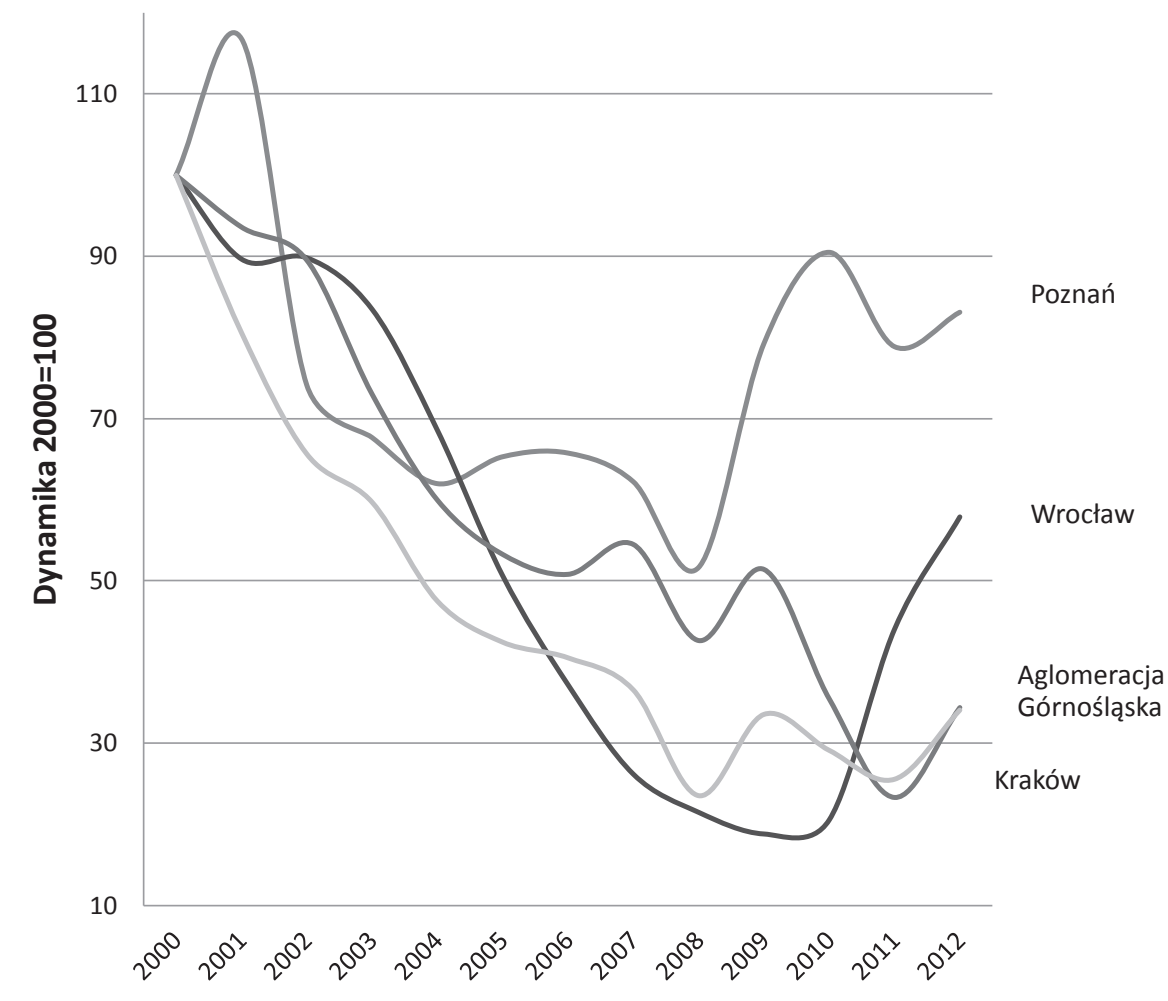

Źródło: opracowanie własne.

W przypadku Krakowa dynamika zwolnień z przyczyn zakładu pracy po 2008 r. wzrosła nieznacznie, a następnie ponownie spadła do poziomu ok. 35 wartości bazowej, co przemawia za relatywnie dużą adaptacyjnością do zmian otoczenia. Wysokie wartości wzrostu dynamiki zwolnień z przyczyn leżących 
po stronie pracodawców po 2008 r. odnoszą się natomiast do Poznania (ostatecznie dynamika analizowanego wskaźnika uplasowała się na poziomie ok. 80 wartości bazowej).

Kalkulując średnie wartości dla wskaźników prężności ekonomicznej (zmienna $x$ ), a także średnie wartości dla wskaźników wrażliwości (zmienna y), możliwe jest uchwycenie długookresowych trajektorii prężności dla poszczególnych miast. Trajektorie tego rodzaju pozwalają z jednej strony na analizę dynamiki rozwoju, z drugiej zaś - na kwalifikowanie danego ośrodka miejskiego do następujących kategorii miast ${ }^{54}$ :

- miasto awangardowe, cechujące się wysoką wartością dla wskaźników prężności i niską wartością dla wskaźników wrażliwości. Tego rodzaju trajektorie prężności można uznać za odporne na zakłócenia zewnętrzne;

- miasto roller-coaster, cechujące się wysoką wartością wskaźników prężności, ale także wysoką wartością wskaźników wrażliwości. Tego rodzaju trajektoria prężności przemawia za dużą zmiennością sytuacji ekonomicznej miasta, która podlega silnym wpływom zakłóceń zewnętrznych, niemniej odzyskuje poprzednie parametry;

- miasto zatopione, cechujące się niskimi wartościami dla wskaźników prężności i równocześnie wysokimi wartościami wskaźników wrażliwości. Tego rodzaju niekorzystna kombinacja dynamik powoduje, że dany ośrodek miejski zazwyczaj boryka się z problemem stagnacji po doznanych zakłóceniach zewnętrznych;

- miasto wyspa, to przykład ośrodka miejskiego, dla którego zarówno wskaźniki dynamik prężności, jak i wrażliwości przyjmują niskie wartości. Oznacza to sytuację miasta posiadającego relatywnie zamknięta gospodarkę, na które nie oddziałują w znaczącym stopniu zaburzenia zewnętrzne. Niemniej jest to także miasto, które posiada relatywnie słabo rozwinięta gospodarkę realizowaną przy niskim poziomie zatrudnienia.

Mając na uwadze powyższe, trajektorie prężności dla analizowanych jednostek samorządu terytorialnego zaprezentowano na wykresie 9.

Analiza przykładowej trajektorii prężności Poznania, pozwala zauważyć, że w latach 2000-2003 dynamika rozwoju w ujęciu ekonomicznym posiadała typowe cechy miasta typu roller-coaster. Natomiast od 2004 do 2008 r. dynamikę rozwoju Poznania można utożsamiać z typowymi cechami miasta awangardowego, co oznacza, że miasto zarówno wzmacniało atrybuty prężności, jak i osłabiało atrybuty wrażliwości. Po 2008 r. Poznań nadal utrzymuje się $\mathrm{w}$ kategorii miast awangardowych, jednak $\mathrm{w}$ latach 2008-2012 następuje zmiana kierunku trajektorii, tj. osłabienie wartości atrybutów prężności przy równoczesnym zwiększeniu wartości atrybutów wrażliwości.

${ }^{54}$ A. Drobniak, The Urban Resilience - Economic Perspective, „Journal of Economics and Management" 10, 2012, s. 5-20. 


\section{Wykres 9}

Dynamika wskaźnika udziału bezrobotnych zwolnionych z przyczyn po stronie przedsiębiorstwa w ogóle bezrobotnych w latach 2000-2012

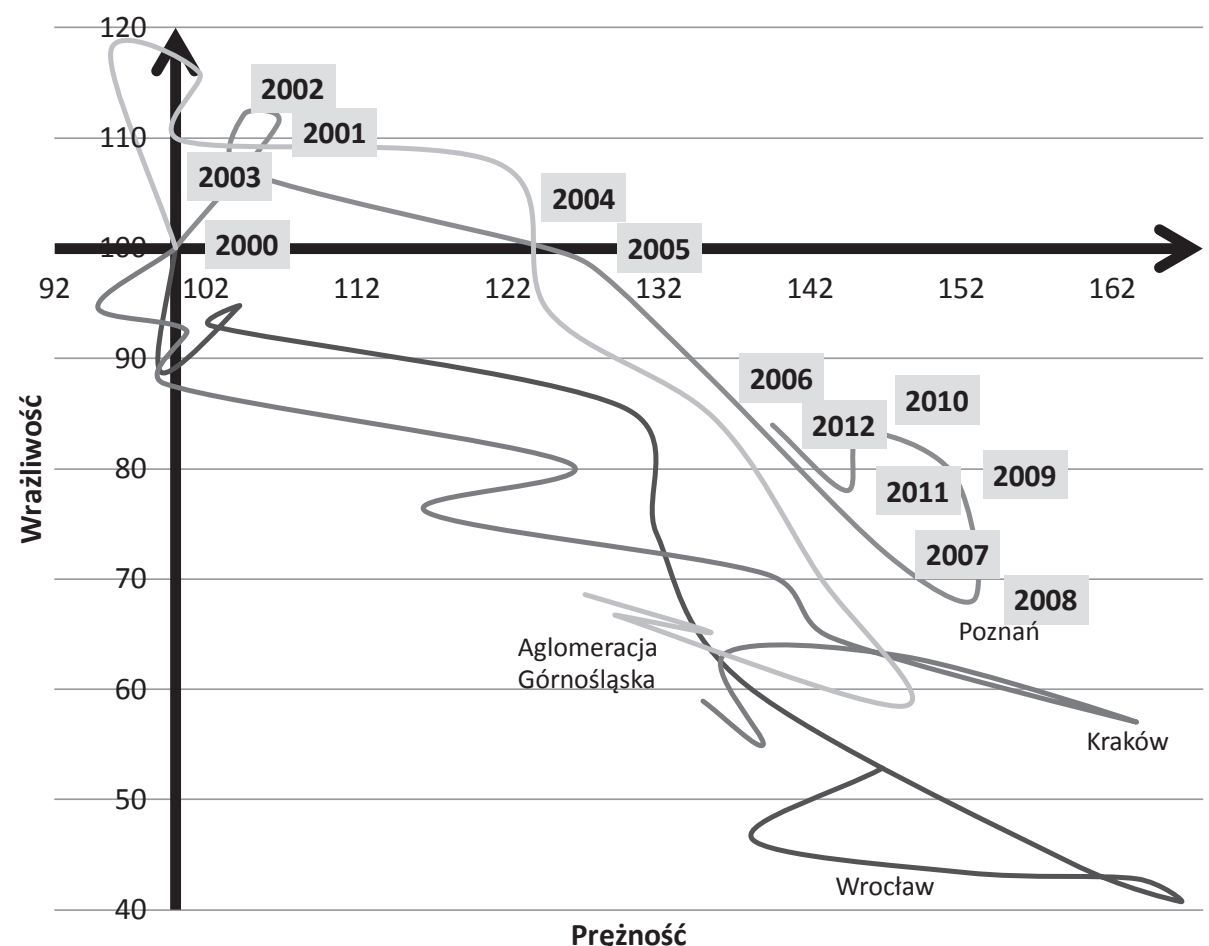

Źródło: opracowanie własne.

Najkorzystniejszą z punktu widzenia ekonomicznej prężności miejskiej trajektorię rozwoju posiada Wrocław. W zasadzie w całym analizowanym okresie dynamika rozwoju ekonomicznego tego ośrodka miejskiego plasuje go w grupie miast awangardowych. W latach 2008-2011 (lata po kryzysie finansowym) następuje co prawda osłabienie prężności ekonomicznej, natomiast nie zwiększa się w tym okresie znacząco wrażliwość.

\section{WNIOSKI}

Zaprezentowana propozycja metodyki badawczej w zakresie oceny prężności miejskiej wprowadza usystematyzowane podejście dotyczące strategicznego diagnozowania dotychczasowej sytuacji rozwojowej miasta w kontekście zmian otoczenia. Diagnoza strategiczna realizowana jest za pomocą uporządkowanych atrybutów prężności i wrażliwości systemu miejskiego, który po- 
strzegany jest jako kompleksowy system adaptacyjny. Dodatkowo wskazane atrybuty dekomponowane są na zestaw czynników prężności oraz wrażliwości miejskiej wraz z towarzyszącymi im wskaźnikami, zarówno ilościowymi, jak i jakościowymi. Zaprezentowana weryfikacja empiryczna wskaźników prężności i wrażliwości w wymiarze ekonomicznym wskazuje, iż mogą być one podstawą wnioskowania na temat:

- charakteru zmian, jakie wiążą się z dynamiką rozwoju miast oraz jej interpretacją $\mathrm{w}$ kategoriach zewnętrznych zakłóceń bądź też zewnętrznych czynników sprzyjających rozwojowi;

- trajektorii prężności pozwalających na zaklasyfikowanie ekonomicznych struktur miejskich do kategorii miast: odpornych na zakłócenia zewnętrzne, podlegających zakłóceniom i odzyskujących pierwotną ścieżkę rozwoju, nieodpornych na zakłócenia zewnętrzne lub też miast o relatywnie zamkniętej gospodarce.

Z punktu widzenia monitoringu i diagnozy strategicznej zaproponowana metodyka badawcza może znaleźć zastosowanie m.in. do:

- doboru wskaźników monitoringu na podstawie atrybutów prężności i wrażliwości miejskiej oraz ich dekompozycji na czynniki wspierające prężność i pogłębiające wrażliwość,

- prowadzenia usystematyzowanych analiz diagnostycznych typu desk research, w tym długookresowych, umożliwiających śledzenie ścieżek rozwoju miast,

- kompleksowego spojrzenia na procesy rozwoju miast z punktu widzenia własności ich struktur ekonomicznych oraz charakteru wpływu otoczenia,

- wnioskowania na temat rekomendacji strategicznych w zakresie wspierania atrybutów prężności miasta oraz osłabiania atrybutów wrażliwości.

Zgodnie z wynikami zaprezentowanych badań empirycznych należy stwierdzić, że miasta poprzemysłowe Aglomeracji Górnośląskiej wykazują wyższą wrażliwość na zakłócenia płynące z otoczenia (reformy branż tradycyjnych $\mathrm{w}$ latach dziewiecćdziesiątych, spowolnienie gospodarcze w latach 2000-2003, kryzys finansowy zapoczątkowany w 2008 r.) niż ośrodki miejskie nieposiadające silnej spuścizny poprzemysłowej. W wielu przypadkach (np. liczba miejsc pracy) miasta poprzemysłowe na skutek zakłóceń otoczenia w latach 19952012 nie odzyskały utraconego potencjału z roku bazowego. Mniej korzystna jest także efektywność różnych form działalności gospodarczej prowadzonych na ich terenie. Zdecydowanie korzystniejsze trajektorie prężności odnoszą się do miast niezwiązanych $\mathrm{w}$ przeszłości z dominacją sektorów tradycyjnych. Kraków, Poznań i Wrocław w okresach dobrej koniunktury gospodarczej wykazują korzystniejszą dynamikę rozwoju dla badanych wskaźników prężności. Są równocześnie bardziej odporne na zakłócenia zewnętrzne, co obrazują niższe wartości dynamik dla wskaźników łączących się z wrażliwością miejska w ujęciu ekonomicznym.

dr hab. Adam Drobniak

Profesor Uniwersytetu Opolskiego

oraz Uniwersytetu Ekonomicznego w Katowicach

adam.drobniak@ue.katowice.pl 


\section{URBAN RESILIENCE CONCEPT: CITIES' STRATEGIC DIAGNOSIS AND MONITORING TOOL}

\section{Summary}

The aim of this paper is to present a proposal for a research methodology in relation to the evaluation of urban resilience and its verification in selected Polish cities. The scope of the article was supplemented by conclusions drawn from the application of the proposed method in the processes of strategic diagnosis and monitoring of cities. The proposed method for the evaluation of urban resilience assumes that a city is an open adaptive system, consisting of the attributes of resilience and vulnerability whose evaluation is a part of the strategic diagnosis leading to the identification of measures to strengthen its resilience. 
